\title{
Is Covid-19 vaccine truly the miracle drug the world was waiting for?
}

\author{
Shazia Durrani Fakhir, Ammara Hameed
}

\begin{abstract}
How to cite this Article:
Fakhir SD, Hameed A. Is Covid-19 vaccine truly the miracle drug the world was waiting for and can it alone save the world from this pandemic?. J Bahria Uni Med Dental Coll. 2021; 11(2):96-98 DOI: https://doi.org/10.51985/TRLH8681

This is an Open Access article distributed under the terms of the Creative Commons Attriution Non Commercial Liciense (http:// creativecommons/org/licences/by-nc/4.0) which permits unrestricted non commercial use, distribution and reproduction in any medium, provided the original work is properly cited.
\end{abstract}

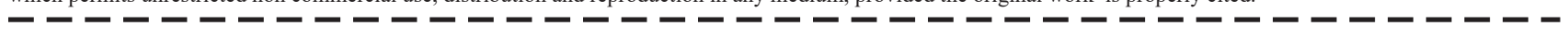

\section{BACKGROUND:}

World is in the middle of COVID-19 pandemic. COVID19 was declared as a pandemic by WHO on 11, March 2020. ${ }^{1}$ Globally 108 million cases have been reported worldwide, claiming the deaths of 2.32 million globally. ${ }^{2}$ The need for wearing masks, frequent hand washing and social distancing cannot be emphasized more since the surge of this pandemic. Now wearing mask and adopting the social distancing are more of a routine. But these measures are certainly not enough to control the pandemic. Efforts more than this are required.

As we know from the history, until 1970 smallpox a viral infectious disease has been a pandemic for more than 3000 years, endemic in developing and tropical areas with periodic epidemics worldwide. ${ }^{3}$ in 1980 via effective vaccination small pox was eradicated from the world. Importance of vaccination cannot be undermined, it saves millions of lives each year. Soon after the pandemic was considered uncontrollable, various agencies all over the world began a race to develop an effective vaccine against novel COVID19. Currently more than 50 vaccines are under trial. ${ }^{4}$

\section{Challenges to accept COVID-19 vaccine:}

The major controversy is the reliability, efficacy and possible side effects of the rapidly created vaccine for COVID-19 virus in a hurry to dampen the SARS-COV-2 infections. ${ }^{5}$ In Pakistan, COVID vaccination has been started among the health care workers only. The hesitancy amongst the HCWs slowly decreased as they started receiving the vaccine. Even then the junior doctors and residents were reluctant and the Sindh Government had to order cutting salary to force them to get it done. Reluctance is still present as no one knows the long term side effects might be. Real hesitance is because of the rapidly made vaccine without enough trial time. People

Shazia Durrani Fakhir

I Senior Registrar, Department of Pediatrics

Bahria University Medical and Dental College, Karachi

I

Email: shaziafakhir@hotmail.com

Ammara Hameed

Senior Registrar, Department of Pediatrics

I Bahria University Medical and Dental College, Karachi

Received: 09-03-2021

I Accepted: 22-03-2021

L Accepted: $22-03-2021$ are also confused on which type of vaccine is safest and most efficient. Although the efficiency is related to the immune response of the person receiving it. BCG vaccine efficacy is only $55 \%$ and still all newborns receive the live vaccine as it claims to prevent not the disease but its complications such as TB meningitis. ${ }^{6}$

The fact that COVID-19 virus has been mutated twice in the past one year, vaccine makers have to keep in mind that this vaccine would probably need to be updated according to the mutated versions just like the influenza vaccine needs to be renewed every year. The more important point is to prevent the spread as this virus will mutate more if it is allowed to go through human bodies and given a chance to mutate.

\section{Preventing the COVID-19 spread: Role of physical distancing:}

Vaccine, although has a very significant role in prevention of complications and possible improvement in mortality but the more important thing is prevention of transmission. This is achieved by adapting certain measures like physical distancing, isolation etc. which we know worked. According to $\mathrm{WHO}$, testing and identifying positive cases who are infectious, provide them supportive isolation, tracking and contact tracing, quarantining the contacts, ensure physical distancing, wearing a mask, avoiding crowded places and closed settings, where there are a lot of people, washing hands, respiratory etiquette, staying home especially if you're sick. All these things together have been proven to make a huge difference in bringing down transmission. ${ }^{8}$

Epidemic studies predict that social and physical distancing is exigent in controlling COVID-19. A recent study evaluates the effectiveness of different physical distancing measures in controlling viral transmission., 10,11

\section{Controlling COVID 19 Pandemic- By achieving Herd immunity:}

Another important point to be discussed here is herd immunity. 'Herd immunity' is indirect protection from infectious disease. It occurs when a certain percentage of the population has become immune to a disease, whether through vaccination or previous infections, thus reducing the chances of infection in those individuals who have not developed immunity. Achieving herd immunity naturally 
would lead to unnecessary deaths and suffering in the population. Vaccine is the only alternative method. The percentage of population needed to become immune for herd immunity depends on the particular infection. ${ }^{12}$

The main purpose to establish herd immunity is to protect those individuals from the disease who cannot be vaccinated, including the very young and immune compromised individuals, and ensure that they are still protected against disease..$^{13}$ It is important to understand certain terms to actually know what herd immunity can be achieved to stop transmission. The point at which the proportion of susceptible individuals in a population falls below the threshold required for disease transmission is called Herd immunity threshold.

$R_{0}$ is the average number of secondary infections caused by a solitary infectious person presented into a completely susceptible population.

Assuming an $\mathrm{R}_{0}$ (basic reproductive number) estimate of 3 for SARS-CoV-2, the herd immunity threshold is approximately $67 \% .13,14,15$ which means that herd immunity for SARS-CoV-2 to be achieved, $67 \%$ of the population need to be vaccinated.

\section{COVID-19 Vaccination- Concerns about side effects:}

Another major concern is the possible side effects of vaccines. The decision of giving vaccine is made after establishing a balance between the side effects of the infection and the vaccine. The suffering of the disease should outweigh the danger of the vaccine side effects. ${ }^{16}$

\section{COVID-19 Vaccination- Myths among the masses:}

One more major hindrance in vaccine acceptance is the Myths and mis-concepts. Anti-vaxxers are the individuals who have faith that vaccination can lead to medical ailments. Some of these anti-vaxxers have dedicated their whole lives to railing against vaccines. Some of the myths include:

- As COVID-19 vaccine has been developed in a very small time frame as compared to the usual 10 to 15 years of any other vaccine development, it might be unsafe.

- The COVID-19 vaccine can cause DNA mutations. - Getting vaccinated for COVID-19 can give you COVID-19 infection.

- The COVID-19 vaccines have microchips!

- The COVID-19 vaccination can lead to women infertility.

- There is fetal tissue in COVID-19 vaccine.

- If someone has already been infected with COVID19 virus, he/she does not need the COVID-19 vaccine anymore.

- If anyone receives the COVID-19 vaccine there is no chance for him to transmit the virus.

- If anyone has been vaccinated for COVID-19, there is no more need of social distancing and other precautions taken to prevent the spread of virus.

- COVID-19 vaccination can provide life time immunity.

- Someone with other chronic diseases cannot be vaccinated for COVID-19.
- Elderly population should not receive the vaccine for COVID-19.

Scientists were studying SARS-CoV-2 for a decade or more before it became pandemic and did simultaneous trials as volunteer availability was not an issue worldwide and hence were able to complete it in one year time. Vaccine is made of mRNA, and cannot alter DNA. mRNA is a transmitter to translator protein and does not even reach the nucleus where DNA is stored. COVID-19 vaccine is dead vaccine and hence cannot cause the disease. In short all these and more myths can be scientifically explanation and have been debunked by WHO and CDC authorities..$^{17,18}$

Take-home message: It is difficult to believe that 1 year ago, COVID-19 and SARS-CoV-2 were almost unknown. Now we have quite a few reliable, viable, effective and safe vaccines.

In the current technological era, rumors propagate and spread like wildfire. In addition, feelings of fear and anxiety provide the perfect growth of stubborn and dangerous myths. The situation is changing and the science is progressing rapidly. The best advice would be to ensure that you always take information from reliable sources and do not pay attention to powerful but misleading social media posts. ${ }^{19}$

\section{CONCLUSION:}

Despite unknown mild to moderate side effects of currently developed vaccine against SARS-CoV-2 virus, apart from continue practicing SOPs, availability of an effective vaccine is the only ray of hope in the battle against COVID-19 pandemic. $^{20}$

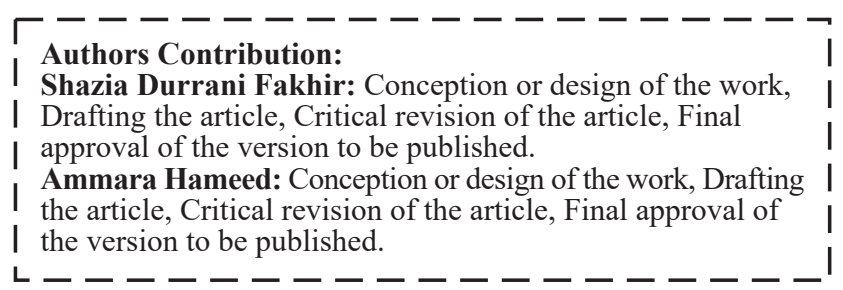

\section{REFERENCES:}

1. Cucinotta D, Vanelli M. (2020) WHO Declares COVID-19 a Pandemic. Acta Biomed. 2020 Mar 19;91(1):157-160. doi: 10.23750/abm.v91i1.9397. PMID: 32191675; PMCID: PMC7569573.

2. Coronavirus Update (Live): $107,037,467$ Cases and $2,337,368$ Deaths from COVID-19 Virus Pandemic - Worldometer [Internet]. Worldometers.info. 2021 [cited 9 February 2021]. Available from: https://www.worldometers.info/coronavirus/

3. Nishiyama Y, Matsukuma S, Matsumura T, Kanatani Y, Saito T.(2015) Preparedness for a smallpox pandemic in Japan: public health perspectives. Disaster Med Public Health Prep. 2015;9(2):220-223. doi:10.1017/dmp.2014.157

4. COVID-19 vaccines [Internet]. Who.int. 2021 [cited 11 February 2021]. Available from: https://www.who. int/emergencies/diseases/novel-coronavirus-2019/covid-19vaccines 
5. Chirumbolo S. Vaccination hesitancy and the "myth" on mRNA-based vaccines in Italy in the COVID-19 era: does urgency meet major safety criteria?. Journal of Medical Virology. 2021 Mar 5. doi: 10.1002/jmv.26922. Epub ahead of print. PMID: 33666240.

6. Colditz GA, Brewer TF, Berkey CS,et all (1994) Efficacy of $\mathrm{BCG}$ vaccine in the prevention of tuberculosis. Meta-analysis of the published literature. JAMA. 1994 Mar 2;271(9):698702. PMID: 8309034.

7. Abubakar I, Pimpin L, Ariti C, Beynon R, Mangtani P, Sterne JA, Fine PE, Smith PG, Lipman M, Elliman D, Watson JM. Systematic review and meta-analysis of the current evidence on the duration of protection by bacillus Calmette-Guérin vaccination against tuberculosis. Health technology assessment (Winchester, England). 2013 Sep;17(37):1. doi: 10.3310/hta17370. PMID: 24021245; PMCID: PMC4781620.

8. Kumbhar PS, Pandya AK, Manjappa AS, Disouza JI, Patravale VB. Carbohydrates-based diagnosis, prophylaxis and treatment of infectious diseases: Special emphasis on COVID-19. Carbohydrate Polymer Technologies and Applications. 2021 Dec 25;2:100052.

9. Omar AM, Halim A. Whole-of-Nation Approach in COVID19 Management: The Case of Brunei Darussalam. InGlobal Perspectives on Change Management and Leadership in the Post-COVID-19 Era 2021;IGI Global. 35-55.

10. Leite JS, Feter N, Caputo EL, Doring IR, Cassuriaga J, Reichert FF, Silva MC, Rombaldi AJ. Managing noncommunicable diseases during the COVID-19 pandemic in Brazil: findings from the PAMPA cohort. Ciência \& Saúde Coletiva. 2021 Mar 15;26:987-1000. doi: 10.1136/bmj.m2743. PMID: 32669358; PMCID: PMC7360923.

11. Chakraborty I, Maity P. COVID-19 outbreak: Migration, effects on society, global environment and prevention. Sci Total Environ. 2020 Aug 1;728: 138882. doi: 10.1016/j. scitotenv.2020.138882. Epub 2020 Apr 22. PMID: 32335410; PMCID: PMC7175860.
12. Smith DR. Herd Immunity.Vet Clin North Am Food Anim Pract. 2019 Nov;35(3):593-604. doi: 10.1016/j.cvfa.2 019.07.001. PMID: 31590904.

13. Randolph HE, Barreiro LB. Herd Immunity: Understanding COVID-19. Immunity. 2020 May 19;52(5):737-741. doi: 10.1016/j.immuni.2020.04.012. PMID: 32433946; PMCID: PMC7236739.

14. Kwok KO, Lai F, Wei WI, Wong SYS, Tang JWT. Herd immunity - estimating the level required to halt the COVID19 epidemics in affected countries. J Infect. 2020 Jun;80(6):e32-e33. doi: 10.1016/j.jinf.2020.03.027. Epub 2020 Mar 21. PMID: 32209383; PMCID: PMC7151357.

15. Aschwanden $\mathrm{C}$. The false promise of herd immunity for COVID-19. Nature. 2020 Nov;587(7832):26-28. doi: 10.1038/d41586-020-02948-4. PMID: 33087872.

16. Destefano, F., Offit, P. A., \& Fisher, A. (2018). Vaccine Safety. Plotkin's Vaccines, 1584-1600.e10. https://doi.org/10.1016/B978-0-323-35761-6.00082-1

17. Zacchigna S, Marcello A, Banks L. Spotlight on COVID-19: from biology to therapy and prevention. FEBS J. 2020 Sep;287(17):3606-3608. doi: 10.1111/febs.15530. PMID: 33448629 .

18. Baig M, Jameel T, Alzahrani SH, Mirza AA, Gazzaz ZJ, Ahmad T, Baig F, Almurashi SH. Predictors of misconceptions, knowledge, attitudes, and practices of COVID-19 pandemic among a sample of Saudi population. PLoS One. 2020 Dec 9;15(12):e0243526. doi: 10.1371/journal.pone.0243526. PMID: 33296420; PMCID: PMC7725365.

19. Tim Newman (2021) Addressing 13 COVID-19 vaccine myths. Medical news today.

20. Vignesh R, Shankar EM, Velu V, Thyagarajan SP. Is Herd Immunity Against SARS-CoV-2 a Silver Lining?. Frontiers in immunology. 2020 Sep 30;11:2570. doi: 10.3389/fimmu.2020.586781. PMID: 33101320; PMCID: PMC7554232. 